\title{
Pseudoprogression in lung adenocarcinoma during treatment with nivolumab
}

\author{
Toshihide Izumida, Yukio Kawagishi, Hiroshi Tsuji
}

Kurobe City Hospital, Kurobe,

Toyama, Japan

Correspondence to Dr Toshihide Izumida, m07011ti@jichi.ac.jp

Accepted 3 May 2017

CrossMark

\section{To cite: Izumida T,}

Kawagishi Y, Tsuji H. BMJ Case Rep Published Online First: [please include Day Month Year]. doi:10.1136/ bcr-2017-219919

\section{DESCRIPTION}

A 64-year-old male was diagnosed with clinical stage IV lung adenocarcinoma. Biopsy was negative for both epidermal growth factor receptor (EGFR) mutation and anaplastic lymphoma kinase (ALK) rearrangement. We administered five lines of chemotherapy. The disease continued to progress (figure $1 \mathrm{~A}$ ), and the patient received antiprogrammed death(PD)-1 antibody (nivolumab, scheduled at $3 \mathrm{mg} / \mathrm{kg}$ once every 2 weeks). After 2 months, he received supportive care due to progression (figure 1B). After 1 month, CT demonstrated a decrease in the size of the lung cancer and metastases (figure 1C). We concluded that this was an atypical response, or pseudoprogression, caused by the immunotherapeutic agent. After 2 months, nivolumab was reinitiated due to progression (figure 2A). After 1 month, the cancer increased in size (figure $2 \mathrm{~B}$ ), and the histopathology of the
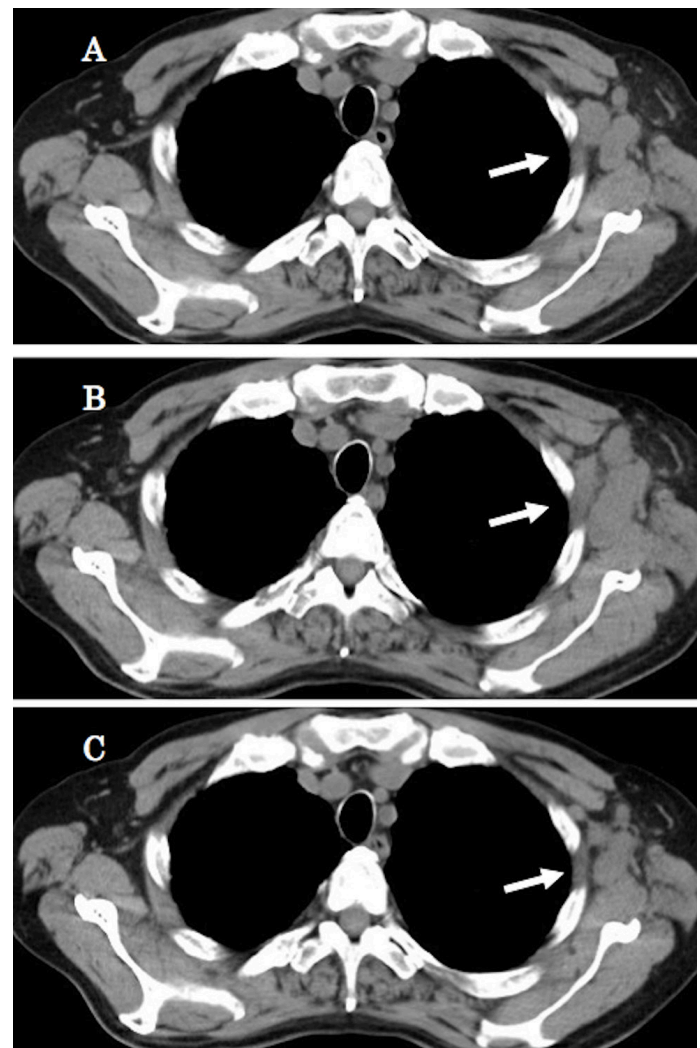

Figure 1 After five lines of chemotherapy for lung adenocarcinoma, CT revealed the enlarged lymph node in the left axilla (A). Eight weeks later, after six cycles of nivolumab treatment, CT revealed that it became larger (B). After 1 month, CT demonstrated a decrease in the size of the lung cancer and metastases (C).
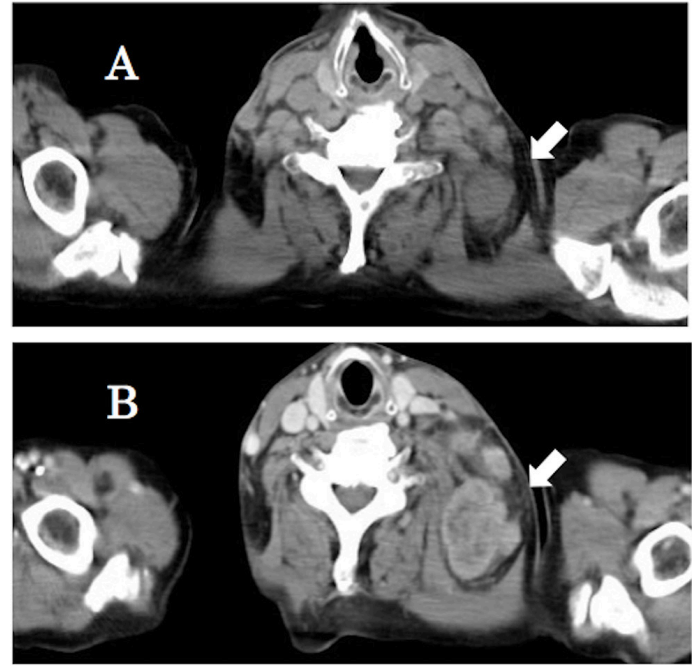

Figure 2 Nivolumab was reinitiated due to progression (A). After 1 month, CT revealed the lung cancer and metastases, especially the left cervical lymph nodes, became larger (B).

specimen obtained from the left cervical lymph nodes showed tumour cells and a mild to moderate inflammatory cell infiltrate (figure 3). His serum CA19-9 levels had increased from $56.9 \mathrm{U} / \mathrm{mL}$ to $2210.0 \mathrm{U} / \mathrm{mL}$, over 4 months. He expired 5 months later.

Nivolumab is a fully humanised monoclonal antibody against a PD-1, which is a key immune-checkpoint receptor expressed by activated $\mathrm{T}$ lymphocytes. ${ }^{1}$ It has been known to cause pseudoprogression. It may be misinterpreted as disease progression and may lead to erroneous treatment decisions. ${ }^{2}$ The presence of a dense inflammatory cell infiltrate may be
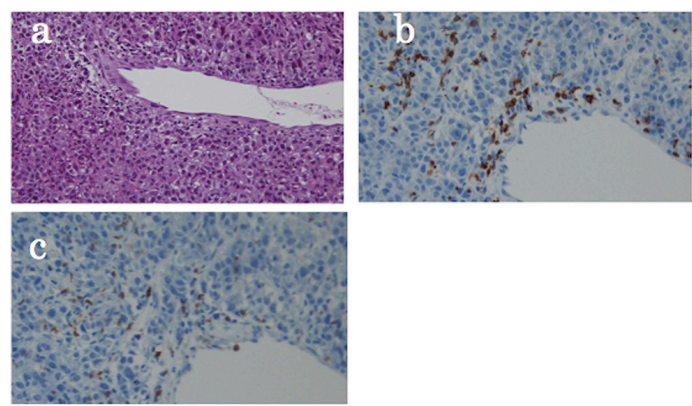

Figure 3 The histopathology of the specimen obtained from these nodes, illustrating tumour cells and a mild to moderate inflammatory cell infiltrate (a; H\&E; $\times 200)$, containing cytotoxic T lymphocytes (b, c: CD3 and CD8, respectively; $\times 400$ ). 


\section{Learning points}

- Nivolumab is a fully humanised monoclonal antibody against a programmed death (PD)-1, which is a key immunecheckpoint receptor expressed by activated T lymphocytes.

- Nivolumab has been known to cause pseudoprogression. It may be misinterpreted as disease progression and may lead to erroneous treatment decisions.

- It is important to carefully assess the therapeutic benefit of nivolumab.

useful to distinguish pseudoprogression from progression. ${ }^{3}$ It is unclear when and how to assess it by the histopathology of the biopsy specimen. Our experience has led us to carefully assess the therapeutic benefit of nivolumab.

Contributors YK is the guarantor of the content of the manuscript. TI, YK and HT have made substantial contributions to the concept and design, or acquisition of data or analysis and interpretation of data; have drafted the submitted article or revised it critically for important intellectual content; have provided final approval of the version to be published; and have agreed to be accountable for all aspects of the work in ensuring that questions related to the accuracy or integrity of any part of the work are appropriately investigated and resolved. Concept and design: TI, YK and HT. Acquisition of data: TI, YK and HT. Analysis/interpretation of data: TI, YK and HT. Approval of manuscript: TI, YK and HT.

Competing interests None declared.

Patient consent Consent obtained from guardian.

Provenance and peer review Not commissioned; externally peer reviewed.

(c) BMJ Publishing Group Ltd (unless otherwise stated in the text of the article) 2017. All rights reserved. No commercial use is permitted unless otherwise expressly granted.

\section{REFERENCES}

1 Gandini S, Massi D, Mandalà M. PD-L1 expression in Cancer patients receiving anti PD-1/PD-L1 antibodies: a systematic review and meta-analysis. Crit Rev Oncol Hematol 2016;100:88-98.

2 Chiou VL, Burotto M. Pseudoprogression and Immune-Related response in solid tumors. J Clin Oncol 2015;33:3541-3.

3 Di Giacomo AM, Danielli R, Guidoboni M, et al. Therapeutic efficacy of ipilimumab, an anti-CTLA-4 monoclonal antibody, in patients with metastatic melanoma unresponsive to prior systemic treatments: clinical and immunological evidence from three patient cases. Cancer Immunol Immunother 2009;58:1297-306.

Copyright 2017 BMJ Publishing Group. All rights reserved. For permission to reuse any of this content visit

http://group.bmj.com/group/rights-licensing/permissions.

BMJ Case Report Fellows may re-use this article for personal use and teaching without any further permission.

Become a Fellow of BMJ Case Reports today and you can:

- Submit as many cases as you like

- Enjoy fast sympathetic peer review and rapid publication of accepted articles

- Access all the published articles

- Re-use any of the published material for personal use and teaching without further permission

For information on Institutional Fellowships contact consortiasales@bmjgroup.com

Visit casereports.bmj.com for more articles like this and to become a Fellow 